\title{
Production of High-Purity Silica Sand from Ivorian Sedimentary Basin by Attrition without Acid Leaching Process for Windows Glass Making
}

\author{
Péyokoh Roger Thio1,2*, Kouassi Bruno Koffi1,2, Kouadio Denis Konan1,2, \\ Kouakou Alphonse Yao ${ }^{2,3}$
}

${ }^{1}$ Mechanics and Materials Science Laboratory, Yamoussoukro, Côte d'Ivoire

${ }^{2}$ National Polytechnic Institute Félix Houphouët-Boigny (INPHB), Yamoussoukro, Côte d'Ivoire

${ }^{3}$ Civil Engineering, Geoscience and Geographic Sciences Laboratory, Yamoussoukro, Côte d'Ivoire

Email: *peyokoh.thio@inphb.ci

How to cite this paper: Thio, P.R., Koffi, K.B., Konan, K.D. and Yao, K.A. (2021) Production of High-Purity Silica Sand from Ivorian Sedimentary Basin by Attrition without Acid Leaching Process for Windows Glass Making. Journal of Minerals and Materials Characterization and Engineering, 9, 345-361.

https://doi.org/10.4236/jmmce.2021.94024

Received: April 27, 2021

Accepted: July 13, 2021

Published: July 16, 2021

Copyright $\odot 2021$ by author(s) and Scientific Research Publishing Inc. This work is licensed under the Creative Commons Attribution International License (CC BY 4.0).

http://creativecommons.org/licenses/by/4.0/

\section{(c) (i) Open Access}

\begin{abstract}
To produce high-purity silica sand usable for glass making, the present study was carried out. The objective of this work was to increase the silicon dioxide $\left(\mathrm{SiO}_{2}\right)$ content to at least $99 \%$ using a simple process without chemical input. The raw sand samples were taken from the Ivorian sedimentary basin, from Maféré and Assinie areas, Côte d'Ivoire. Wet sieving and attrition technique were used for the purification process. The results from the energy dispersive spectrometer (EDS) analyses of the raw and treated samples show a significant increase of silica content and a significant reduction of impurities. The silica content $\left(\mathrm{SiO}_{2}\right)$ of the sand of Maféré increases from $98.73 \% \pm 0.15 \%$ to $99.92 \% \pm 0.05 \%$. And the sand of Assinie increased from $98.82 \% \pm 0.67 \%$ in the raw samples to $99.44 \% \pm 0.27 \%$ after treatment. The rate of iron oxide and alumina is reduced in these sands. Moreover, the sand of Maféré contains $53.2 \%$ of grains of size lower than 500 microns and that of Assinie contains $29.30 \%$. Regarding the chemical composition of these purified sands, they meet the standard BS2975s, the American Ceramic Society and the National Bureau of Standards for window glass making.
\end{abstract}

\section{Keywords}

Silica Sand, Silicon Oxide, Attrition, Wet Sieving, Soda Lime Glass, Maféré, Assinie, Côte d'Ivoire 


\section{Introduction}

Window glass making requires the use of very pure silica sand without impurities [1]. Other domains such as photovoltaic cell production, silicon metal wafers, and optical glass are also dependent on good quality silica [2] [3] [4] [5] [6]. The BS2975 (British Standards International) specification published in 2008 specifies the silicon oxide (silica) content and the limits of iron, chromium, and titanium oxides in good quality silica sands. However, natural silica can be used if it meets the quality requirements of the standards [7] [8] [9]. According to this standard, there are three distinct grades of sand named A, B and C. Grade A contains a maximum of $0.008 \% \mathrm{Fe}_{2} \mathrm{O}_{3}, 0.030 \% \mathrm{TiO}_{2}, 2 \mathrm{ppm} \mathrm{Cr}_{2} \mathrm{O}_{3}$ and a minimum of $99.5 \%$ silica, Grade B sand contains a minimum of $99.5 \%$ silicon oxide and a maximum of $0.013 \% \mathrm{Fe}_{2} \mathrm{O}_{3}$ and $2 \mathrm{ppm} \mathrm{Cr}_{2} \mathrm{O}_{3}$, while Grade $\mathrm{C}$ contains a minimum of $98.5 \% \mathrm{SiO}_{2}$, a maximum of $0.035 \% \mathrm{Fe}_{2} \mathrm{O}_{3}$ and 6 ppm $\mathrm{Cr}_{2} \mathrm{O}_{3}$ [9]. Grade A sand is used for the manufacture of optical glass, Grade B sand is used for the manufacture of household objects and colored glass. Grade $\mathrm{C}$ sand, suitable for the manufacture of color less containers etc., should have a maximum $\mathrm{Fe}_{2} \mathrm{O}_{3}$ content of $0.030 \%$ and not more than $6 \mathrm{ppm} \mathrm{Cr}_{2} \mathrm{O}_{3}$. There is a proviso that the $\mathrm{Fe}_{2} \mathrm{O}_{3}$ specification can be relaxed to $0.035 \%$ maximum if the sand contains less than 2 ppm $\mathrm{Cr}_{2} \mathrm{O}_{3}$. A minimum $\mathrm{SiO}_{2}$ content of $98.5 \%$ is specified.

Previous work has led to the discovery of silica sand (S.S) with a high silica content in the Ivorian sedimentary basin [10]. The sands with a high proportion of silicon oxide (silica) are found east of Abidjan up to the border with Ghana. In the locality of Maféré, Aboisso region, Côte d'Ivoire, siliceous sands are found with an average silica content of $97.41 \%$. These sands are fine with $66.8 \%$ of the grains less than or equal to 500 microns in size. The quality of these sands is suitable to produce silica glass [10].

However, pure sand with a silica content of $98 \%$ or more is required to produce window glass. Highly pure silica sands with a silica content of more than $99.00 \%$ are required to produce optical glass and for the manufacture of photovoltaic cells. In this perspective, this study was carried out to propose a method of simple treatment, without the use of chemical products on the said sands. Thus, after the sampling phase, treatment of the samples was carried out in the laboratory using only wet sieving and attrition.

\section{Material and Methods}

\subsection{Collection and Conservation of Samples}

The sampling phase was done according to the method described in our previous work [10] [11]. Samples were taken with an auger at a depth of 50 centimeters. Composite sand samples (S.S) ${ }_{0}$ of 1050 grams were collected in Maféré and Assinie, Côte d'Ivoire. Figure 1 illustrates the location of the sampling sites. The samples were transported to the laboratory in canvas bags free of any contamination at room temperature. 


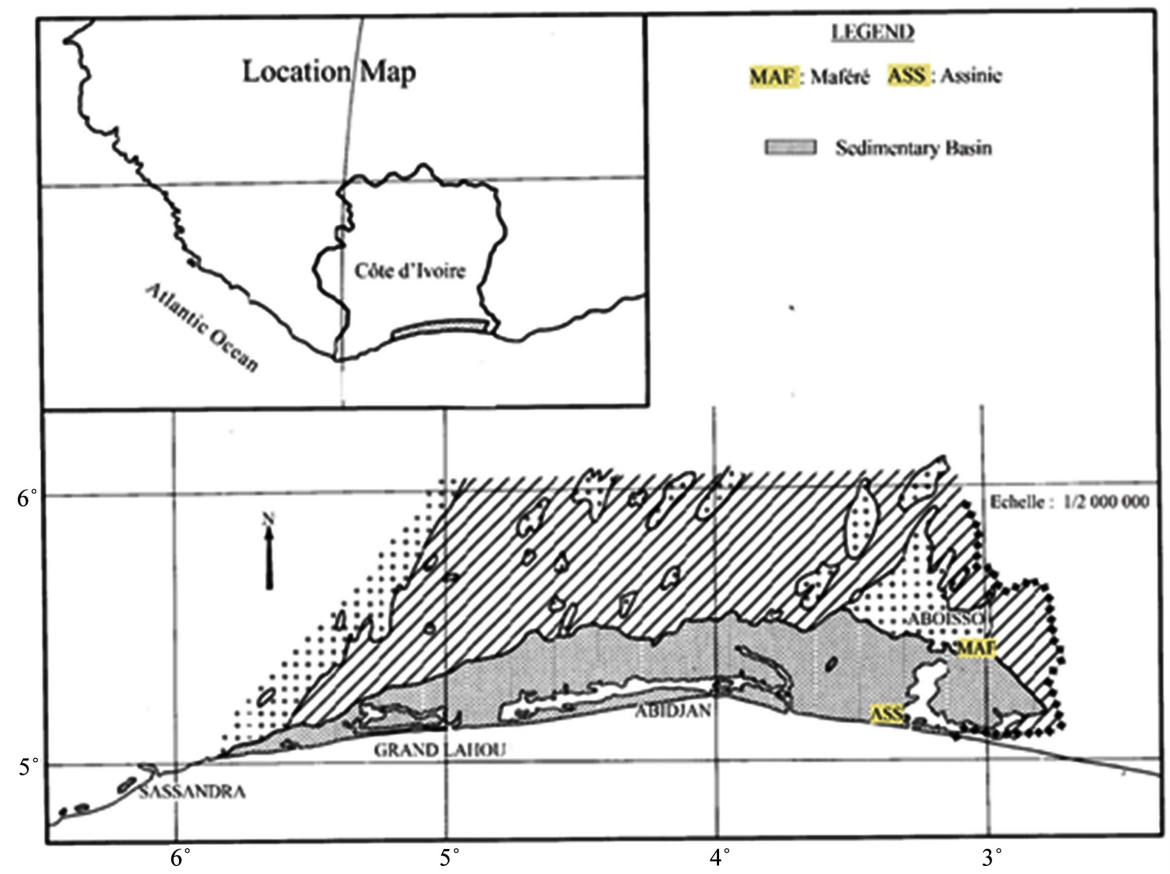

Figure 1. Sand sample collection map ([12] amended).

\subsection{Sample Preparation for the Analysis Phase}

In the laboratory, a fraction of 750 grams of each sample (S.S) $)_{0}$ was dried. The drying was done at 105 degrees Celsius to constant mass. After cooling in the desiccator, a weight of 50 gram of each raw sample was pulverized (to a $75 \mathrm{mi}$ crometers particle size) for chemical composition analysis by energy dispersive spectrometer (EDS). Thereafter, 500 grams of each dried sample was used for particle size analysis. Finally, 200 grams of the raw samples (S.S) $)_{0}$ was utilized for the processing phase.

\subsection{Wet Sieving and Attrition Technique}

The processing procedure begins with wet sieving of $200 \mathrm{~g}$ of the raw samples (S.S $)_{0}$ with distilled water using a one-millimeter mesh size for removal of coarse particles and debris. The passing at this mesh is sifted, still in wet way, to $80 \mathrm{mi}-$ crons for the elimination of the fine clayey fraction and limestones. Thereafter, with the refusal of the sieve to 80 microns the attrition is carried out using the device of Figure 2. The equipment consists of a plastic test tube and an electric agitator used to shake the contents of the test tubes.

Attrition is the most common enrichment method for sand enrichment [13] [14] [15] [16]. In this study, we introduce the 80 microns refusals of each sample into test tubes. Then, 300 milliliters of distilled water were added, and the test tubes were closed tightly. Finally, the mixture of sand and distilled water was agitated by a stirring machine that performs an oscillatory movement (180 oscillations per minute), with an amplitude of 20 centimeters. This movement creates friction between the sand grains. 


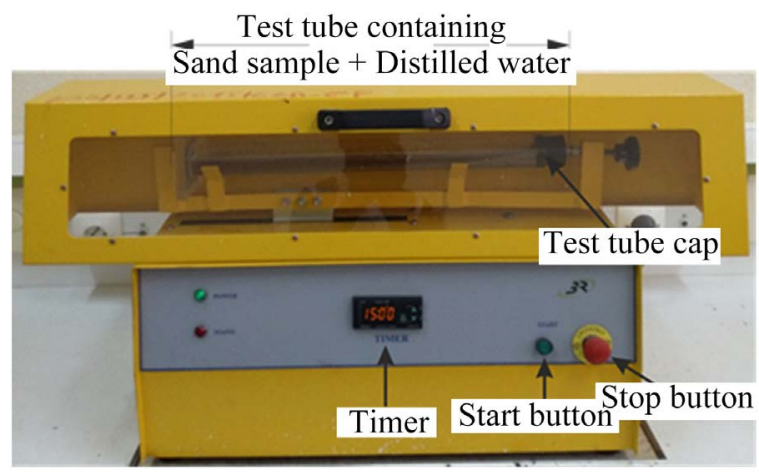

Figure 2. Device used for sample attrition.

The attrition was carried out in two cycles for 15 minutes each [14] [17]. At the end of each 15-minute attrition sequence, the contents of the attrition vessel are sieved to 80 microns with distilled water.

The nomenclature of sand samples adopted in this manuscript is as follows: $(\mathrm{S} . S)_{(i, j)}$ with, $i=\{\mathrm{MAF}$; ASS $\}$ : sampling sites and $j \in \llbracket 0 ; 1 \rrbracket$ : processing level. The Table 1 is the summary of the sample nomenclature.

The product of the last sieving carried out is oven dried. The schematic of the processing protocol is shown in Figure 3.

Finally, a 50-grams fraction of the treated and dried sands is ground for chemical composition analysis.

\subsection{Analysis of the Samples}

Several analyses were carried out on the sand samples. First, the chemical composition of the raw and treated sands was analyzed using the energy dispersive spectrometer (EDS). Then, the granularity of the raw sands was determined. Finally, the micrography of the quartz grains is performed by Scanning Electron Microscope (SEM).

\section{Energy Dispersive Spectrometer (EDS)}

Energy dispersive spectroscopy (EDS) provides elemental and chemical analysis of samples [18] [19]. We use the crushed material of each sample (raw and processed) for the determination of the chemical composition. The principle of this analysis is to first ionize the atoms of the samples. Then the instrument measures the intensity and energy of the X-rays emitted by the atoms. The results of this method are the chemical composition and emission spectra of each sample.

\section{Granulometric analysis}

A weight of 500 grams of each previously dried crude was used. A series of AFNOR sieves $(80 \mu \mathrm{m}, 100 \mu \mathrm{m}, 125 \mu \mathrm{m}, 160 \mu \mathrm{m}, 200 \mu \mathrm{m}, 250 \mu \mathrm{m}, 315 \mu \mathrm{m}, 400$ $\mu \mathrm{m}, 500 \mu \mathrm{m}, 630 \mu \mathrm{m}, 800 \mu \mathrm{m}, 1 \mathrm{~mm}, 1 \mathrm{~mm} .25 \mathrm{~mm}, 1.6 \mathrm{~mm}, 2 \mathrm{~mm}, 2.5 \mathrm{~mm}$ ) are used. The column is placed on a vibrating sieve machine for 10 minutes. Each sieve reject is weighed for determination of the proportions of pass and reject [11]. 
Table 1. Nomenclature of raw and processed samples.

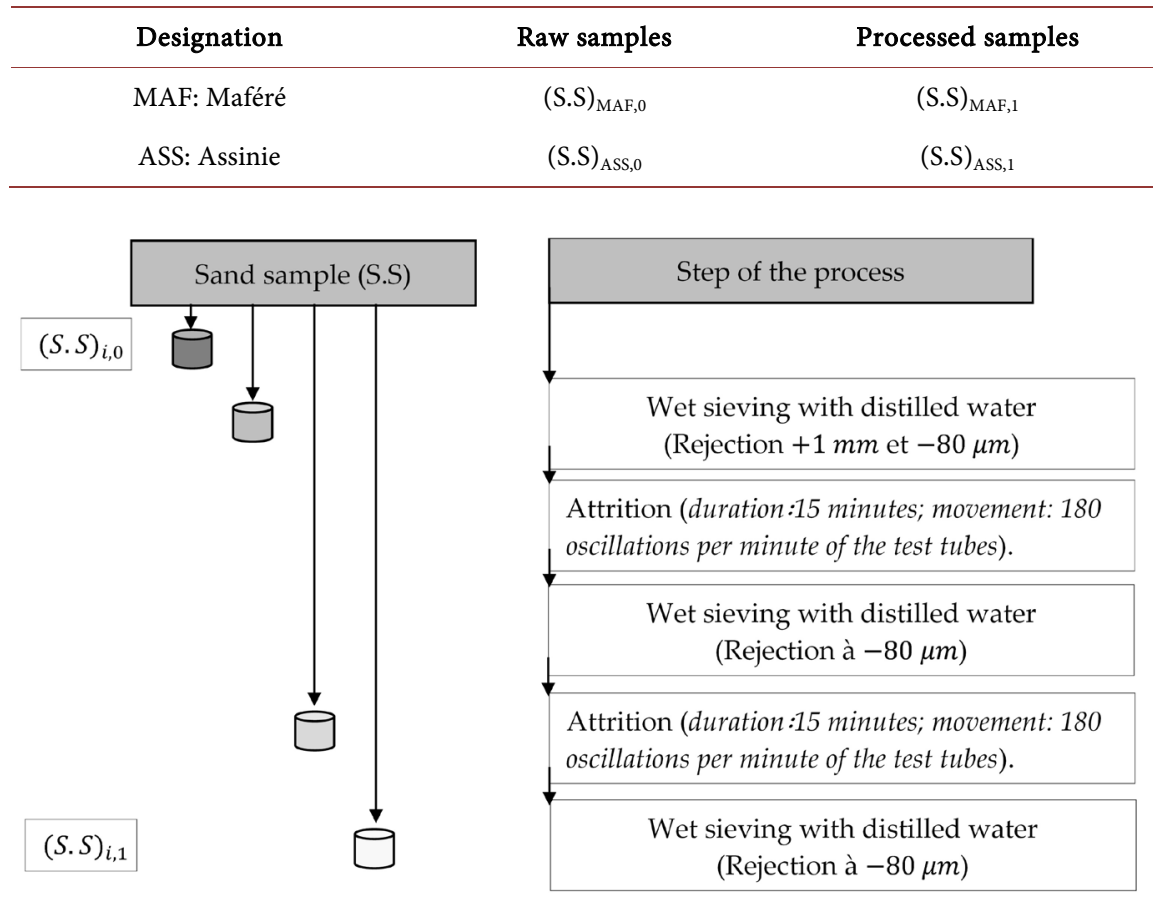

Figure 3. Scheme followed for the purification of silica sand samples.

Data from the particle size analysis are used for sand characterization. We use the method of statistical moments and that of Folk and Ward. These methods are described in the article by Blott and Pye [20]. They proposed a macro run-

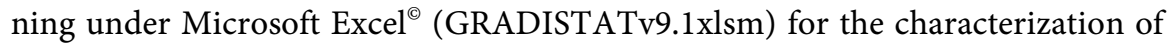
samples based on the particle size analysis. The good grading of the sands is also evaluated using the indices from the method of moments and the Folk and Ward method. These are parameters such as: means, mode(s), standard deviation, skewness, kurtosis, and a range of values of cumulative percentiles (the grain size at which a specified percentage of the grains are coarser), namely $D_{10}, D_{50}, D_{90}$.

The particle size scale used was proposed by Blott [11] [20]. Table 2 illustrates the nomenclature of grain size classes. Grain sizes are expressed in $\mathrm{mm}\left(X_{\mathrm{mm}}\right)$ or $\mu \mathrm{m}\left(x_{\mu \mathrm{m})}\right.$ but also in phi $(\phi)$. The relationship between these units' systems is established by the following expression:

$$
x_{\phi}=-\log _{2}\left(x_{\mathrm{mm}}\right) .
$$

\section{Processing weight efficiency}

Next, we evaluate the yield $(\eta)$ of the processing method for raw sand samples.

The adopted calculation method is illustrated by the formulas in Table 3 and in Table 4. We use the results of the spectrometric analysis to calculate the different yields.

These formulas, Table 3, and Table 4 consider the objective of silica sand treatment, which is to increase the silica content to $100 \%$ by removing impurities [21]. Indeed, a treatment method would be efficient (ideal) if it allows the reduction of impurities to $0 \%$ and raises the silica content to $100 \%$. Thus, we 
calculated the yield on the silica content by the ratio of the difference between the final proportion (example $\mathrm{T}_{\text {(silica)MAF, } 1}$ ) and the initial proportion (example $\mathrm{T}_{\text {(silica)MAF, } 0}$ ) and the difference between $100 \%$ and the initial proportion (example $\mathrm{T}_{(\text {silica)MAF, } 0}$ ). For the impurities, the calculation of the yield was using the difference between $0 \%$ and the initial proportion (example $\mathrm{T}_{(\text {silica)MAF, } 0}$ ) in the denominator.

\section{Scanning Electron Microscope (SEM)}

Exoscopy allows us to observe and interpret this surface condition by analyzing images taken by scanning electron microscopy (SEM), at magnifications typically between $\times 500$ and $\times 20,000$. Nearly 250 characters have been listed [22] [23]. They allow to determine the depositional environment of a grain, its history and sometimes its geographical origin. It is strongly recommended that the 250 - $355 \mu \mathrm{m}$ fraction be preferred [11].

Table 2. Size scale proposed by Blott.

\begin{tabular}{cccc}
\hline & Grain size & Descriptive terminology \\
\hline phi & $\mathrm{mm} / \mu \mathrm{m}$ & Very coarse & coarse \\
\hline-6 to -5 & $32 \mathrm{~mm}-64 \mathrm{~mm}$ & Medium & Gravel \\
-5 to -4 & $16-32$ & Fine & \\
-4 to -3 & $8-16$ & Very fine \\
-3 to -2 & $4-8$ & Very coarse \\
-2 to -1 & $2-4$ & Coarse & Sand \\
-1 to 0 & $1-2$ & Medium & \\
$0-1$ & $500 \mu \mathrm{m}-1 \mathrm{~mm}$ & Fine & \\
$1-2$ & $250 \mu \mathrm{m}-500 \mu \mathrm{m}$ & Very fine &
\end{tabular}

Table 3. Calculation of the yield of the treatment performed for Sand sample of Maféré.

\begin{tabular}{|c|c|}
\hline \multirow{2}{*}{ Compound } & yield of the treatment performed $(\eta)$ \\
\hline & Sand sample of Maféré \\
\hline Silica & $\eta_{(\text {silica })}=\left[\mathrm{T}_{(\text {silica)MAF, } 1}-\mathrm{T}_{(\text {silica)MAF, } 0}\right] /\left[100-\mathrm{T}_{(\text {silica }) M A F, 0)}\right] \times 100$ \\
\hline Iron oxide & $\eta_{\text {(iron) }}=\left[\mathrm{T}_{\text {(iron)MAF, } 1}-\mathrm{T}_{\text {(iron)MAF }, 0}\right] /\left[0-\mathrm{T}_{\text {(iron)MAF, } 0}\right] \times 100$ \\
\hline Alumina & $\eta_{(\text {alumina })}=\left[\mathrm{T}_{(\text {alumina)MAF, } 1}-\mathrm{T}_{(\text {alumina)MAF, } 0}\right] /\left[0-\mathrm{T}_{(\text {alumina)MAF }, 0}\right] \times 100$ \\
\hline
\end{tabular}

Table 4. Calculation of the yield of the treatment performed for Sand sample of Assinie.

\begin{tabular}{cc}
\hline \multirow{2}{*}{ Compound } & yield of the treatment performed $(\eta)$ \\
\cline { 2 - 2 } Silica & Sand sample of Maféré \\
Iron oxide & $\eta_{(\text {silica) }}=\left[\mathrm{T}_{(\text {silica)ASS, } 1}-\mathrm{T}_{(\text {silica)ASS, }, 0}\right] /\left[100-\mathrm{T}_{(\text {silica)ASS }, 0)}\right] \times 100$ \\
Alumina & $\eta_{\text {(iron) }}=\left[\mathrm{T}_{(\text {iron)ASS, } 1}-\mathrm{T}_{(\text {iron)ASS, }, 0}\right] /\left[0-\mathrm{T}_{(\text {iron)ASS, } 0}\right] \times 100$ \\
\hline
\end{tabular}




\section{Results and Discussion}

At the end of the implementation and the different analyses carried out on the sand samples, some results were found.

\subsection{Particle Size Analysis}

Glass production requires sand with a fine grain size of about 200 microns to 500 microns [13] [14]. Figure 4 and Figure 5 represent the graphical results of the particle size analysis of the sands of Maféré and Assinie respectively. These figures show the proportions of passing on the sieves of the AFNOR series (from 80 microns to 2.5 millimeters).

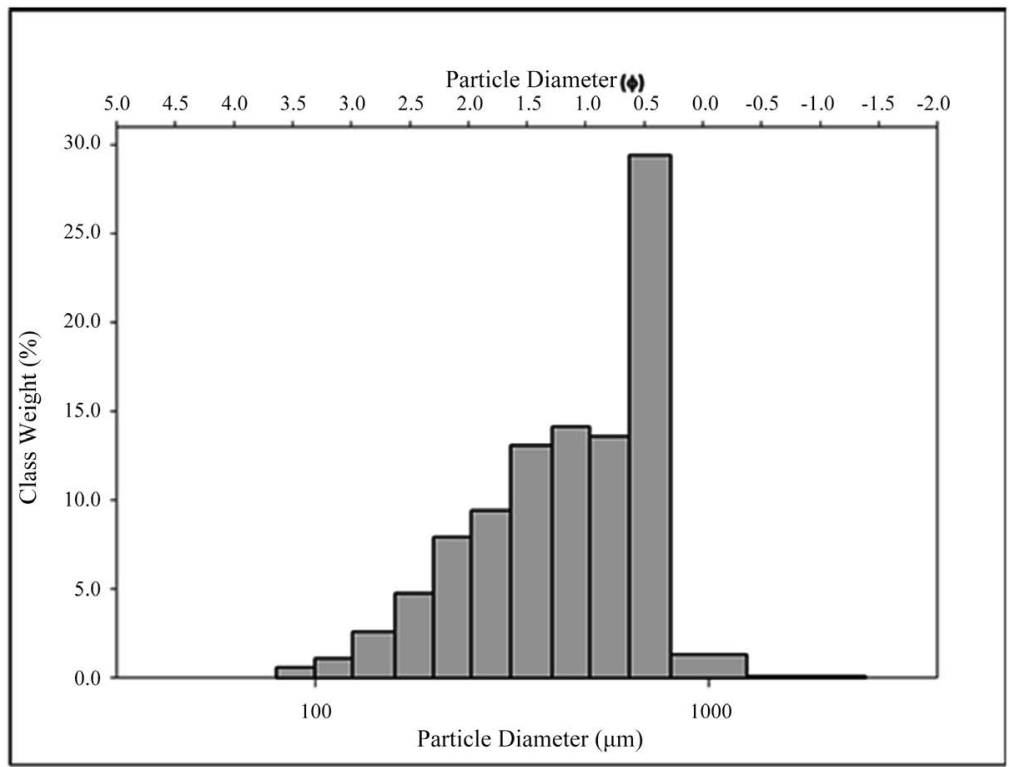

Figure 4. Grain size distribution of Maféré Sand.

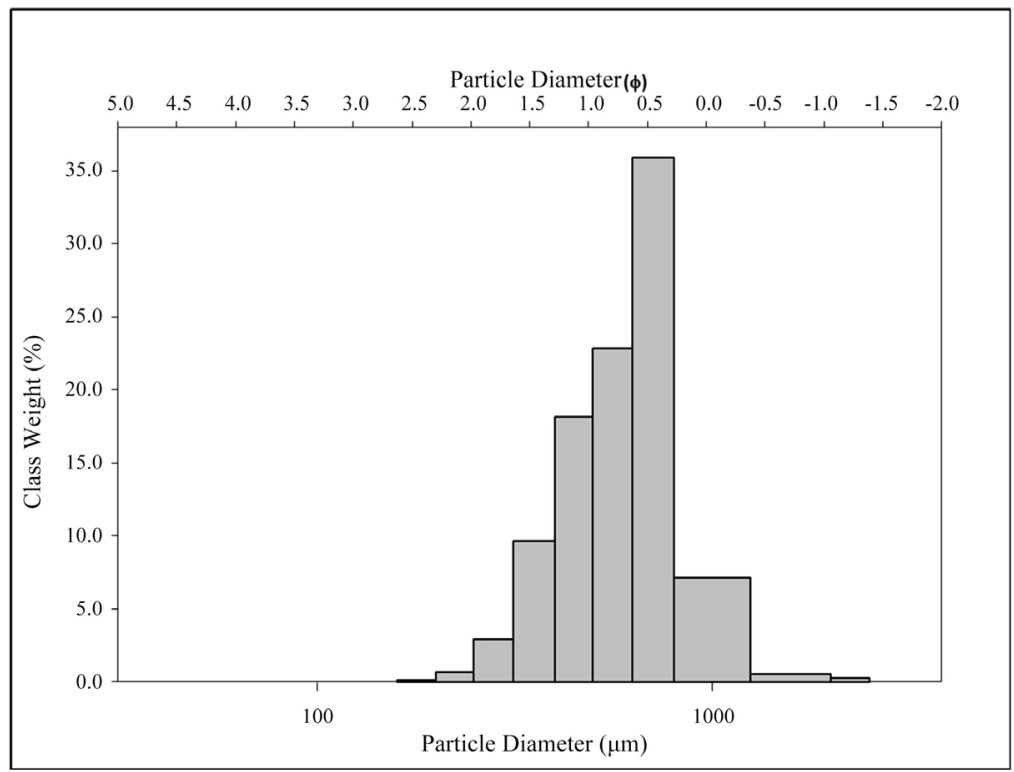

Figure 5. Grain size distribution of Assinie Sand. 
The grain size distribution of Maféré sand is bimodal with one modal value at 450 micrometers and the other at 715 micrometers (respectively $\phi=0.494$ and $\phi$ $=1.61$ ) (see Figure 4 and Table 5). Other position indices such as $\mathrm{D}_{10}$ and $\mathrm{D}_{90}$ are equal to $206(\phi=0.403)$ micrometers and 756 micrometers $(\phi=2.278)$ respectively.

Also, in the Sand-Clay-Silt diagram, the Maféré sample is a sand containing $53.2 \%$ of grains smaller than 500 microns (Figure 6). There are $26.6 \%$ of grains between 250 microns and 500 microns in this sand.

Furthermore, according to the indices calculated by the method of moments and by the method of Folk and Ward (see Table 6), the sand of Maféré is a medium sand, moderately sorted. The fine granularity of the sand up to 125 microns is suitable for glass production [10] [13].

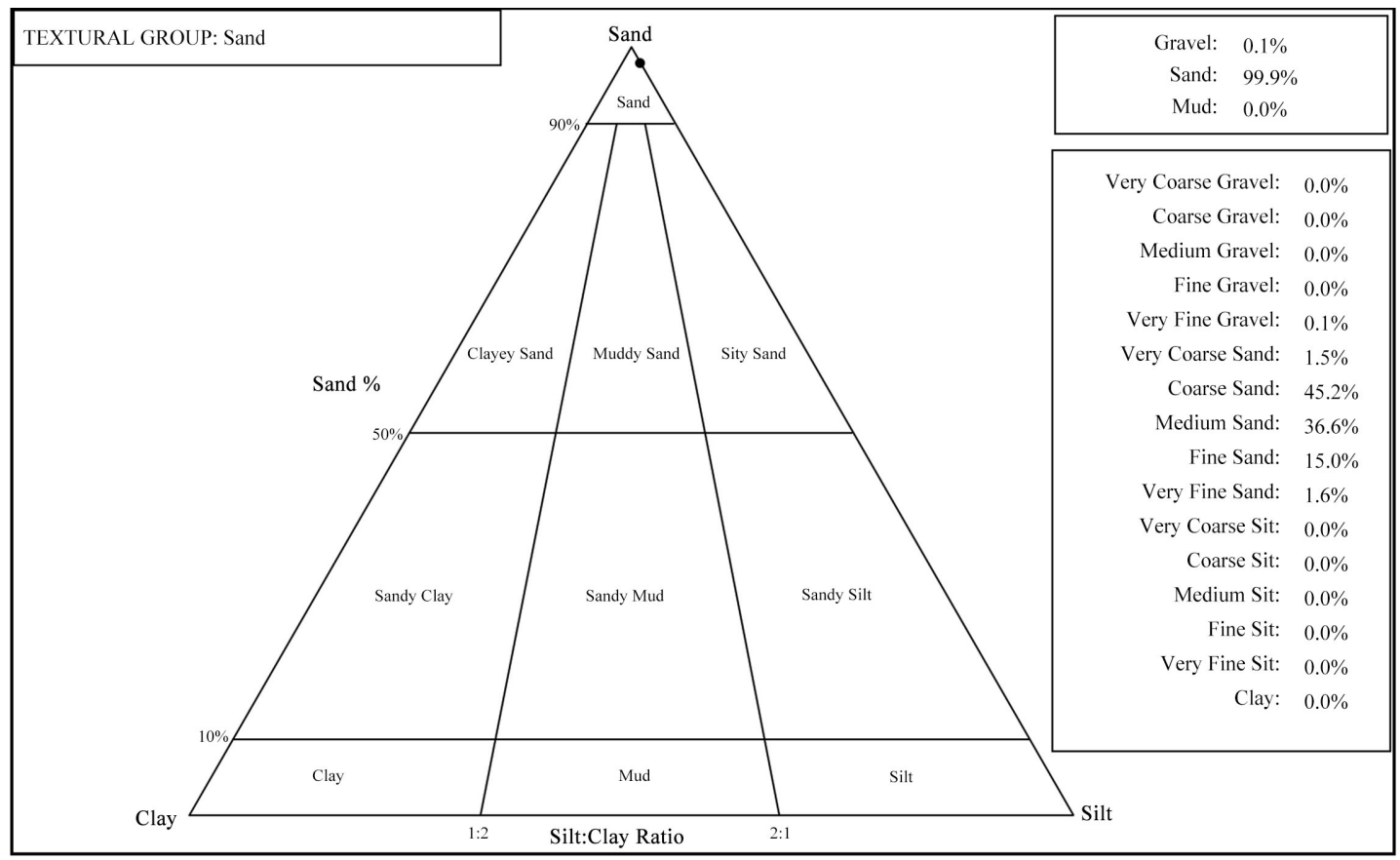

Figure 6. Maféré sand in the ternary Sand-Clay-Silt diagram.

Table 5. Statistical parameters of position of Maféré sand and Assinie Sand.

\begin{tabular}{ccccc}
\hline Sample & $\mathrm{D}_{10}$ & Median $\left(\mathrm{D}_{0}\right)$ & Mode(s) & $\mathrm{D}_{90}$ \\
\hline$(\mathrm{S} . \mathrm{S})_{\mathrm{MAF}, 1}$ & $206 \mu \mathrm{m}$ & $474 \mu \mathrm{m}$ & $450 \mu \mathrm{m}$ and $715 \mu \mathrm{m}$ & $756 \mu \mathrm{m}$ \\
$(\mathrm{S} . S)_{\mathrm{ASS}, 1}$ & $372 \mu \mathrm{m}$ & $624 \mu \mathrm{m}$ & $715 \mu \mathrm{m}$ & $924 \mu \mathrm{m}$ \\
\hline
\end{tabular}

Table 6. Parameters of the method of moments and the method of Folk and Ward of Maféré sand.

\begin{tabular}{|c|c|c|c|c|c|c|}
\hline \multirow[b]{2}{*}{ Parameters } & \multicolumn{3}{|c|}{ Method of moments } & \multicolumn{2}{|c|}{ Folk and Ward's method } & \multirow[b]{2}{*}{ Description } \\
\hline & $\begin{array}{l}\text { Arithmetic } \\
(\mu \mathrm{m})\end{array}$ & $\begin{array}{c}\text { Geometric } \\
(\mu \mathrm{m})\end{array}$ & $\begin{array}{l}\text { Logarithmic } \\
\text { phi }(\phi)\end{array}$ & $\begin{array}{c}\text { Geometric } \\
(\mu \mathrm{m})\end{array}$ & $\begin{array}{l}\text { Logarithmic } \\
\text { phi }(\phi)\end{array}$ & \\
\hline Mean & 492.663 & 434.026 & 1.204 & 438.087 & 1.191 & Medium Sand \\
\hline Sorting & 225.084 & 1.676 & 0.745 & 1.658 & 0.730 & Moderately Sorted \\
\hline Skewness & 0.726 & -0.645 & 0.645 & -0.288 & 0.288 & Fine Skewed \\
\hline Kurtosis & 6.062 & 2.845 & 2.845 & 0.817 & 0.817 & Platykurtic \\
\hline
\end{tabular}


In the case of the Assinie sample, its particle size distribution is unimodal. The modal value is 715 micrometers (respectively $\phi=0.494$ ) (see Figure 7 and Table 7). Other positional indices such as $\mathrm{D}_{10}$ and $\mathrm{D}_{90}$ are equal to $372(\phi=0.114) \mathrm{mi}$ crometers and 924 micrometers $(\phi=1.425)$ respectively.

In the Sand-Clay-Silt diagram, the Assinie sample is a sand containing $29.3 \%$ of grains smaller than 500 microns. The proportion of fine phase is very low. There are $0.7 \%$ of grains between 250 microns and 500 microns in this sand (Figure 7).

Moreover, regarding the indices calculated by the method of moments and by the method of Folk and Ward, the sand of Assinie is well sorted around the average diameter. The characteristic curve of its histogram is of mesokurtic form. This sand is coarser than that of Maféré (see Table 4).

Thus, the sand from Maféré would be more useful for glass production than that from Assinie. In addition to the granularity of these sands, we are interested in the chemical composition of these sands.

Table 7. Parameters of the method of moments and the method of Folk and Ward of Assinie sand.

\begin{tabular}{|c|c|c|c|c|c|c|}
\hline \multirow[b]{2}{*}{ Parameters } & \multicolumn{3}{|c|}{ Method of moments } & \multicolumn{2}{|c|}{ Folk and Ward's method } & \multirow[b]{2}{*}{ Description } \\
\hline & $\begin{array}{c}\text { Arithmetic } \\
(\mu \mathrm{m})\end{array}$ & $\begin{array}{l}\text { Geometric } \\
(\mu \mathrm{m})\end{array}$ & $\begin{array}{c}\text { Logarithmic } \\
\text { phi }(\phi)\end{array}$ & $\begin{array}{l}\text { Geometric } \\
(\mu \mathrm{m})\end{array}$ & $\begin{array}{c}\text { Logarithmic } \\
\text { phi }(\phi)\end{array}$ & \\
\hline Mean & 642.7 & 598.7 & 0.740 & 590.8 & 0.759 & Coarse Sand \\
\hline Sorting & 235.5 & 1.415 & 0.501 & 1.408 & 0.494 & Well Sorted \\
\hline Skewness & 1.524 & -0.090 & 0.090 & -0.164 & 0.164 & Fine Skewed \\
\hline Kurtosis & 8.766 & 3.372 & 3.372 & 1.089 & 1.089 & Mesokurtic \\
\hline
\end{tabular}

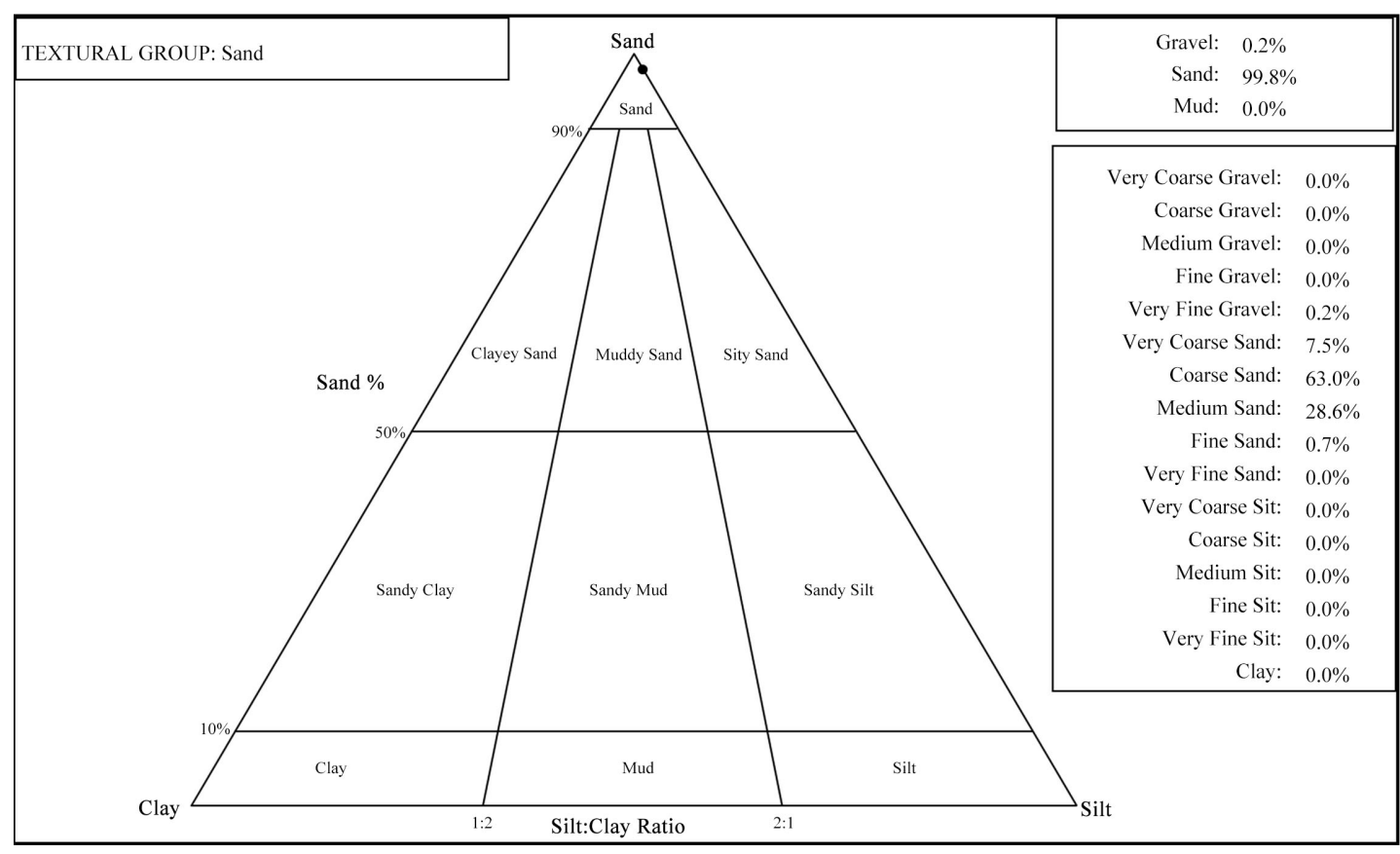

Figure 7. Assinie sand in the Sand-Clay-Silt ternary diagram. 


\subsection{Chemical Composition of Sedimentary Basin Sand}

The results of the chemical composition analysis of the samples are shown in Table 8 and Table 9. Three analyses were performed for each sample.

Table 8. Chemical composition of raw and treated sands from Maféré.

\begin{tabular}{|c|c|c|c|}
\hline \multicolumn{4}{|c|}{$(\mathrm{S} . \mathrm{S})_{\mathrm{MAF}, 0}$} \\
\hline \multirow{2}{*}{ Parameters } & \multicolumn{3}{|c|}{ Chemical compound } \\
\hline & $\mathrm{Al}_{2} \mathrm{O}_{3}(\%)$ & $\mathrm{FeO} / \mathrm{Fe}_{2} \mathrm{O}_{3}(\%)$ & $\mathrm{SiO}_{2}(\%)$ \\
\hline sample 1 & 0.18 & 0.99 & 98.83 \\
\hline sample 2 & 0.24 & 0.97 & 98.79 \\
\hline sample 3 & 0.59 & 0.86 & 98.56 \\
\hline Mean & 0.33 & 0.94 & 98.73 \\
\hline Std. deviation & 0.22 & 0.07 & 0.15 \\
\hline \multicolumn{4}{|c|}{$(\mathrm{S} . \mathrm{S})_{\mathrm{MAF}, 1}$} \\
\hline & $\mathrm{Al}_{2} \mathrm{O}_{3}(\%)$ & $\mathrm{FeO} / \mathrm{Fe}_{2} \mathrm{O}_{3}(\%)$ & $\mathrm{SiO}_{2}(\%)$ \\
\hline Sample 1 & 0.09 & 0.03 & 99.88 \\
\hline sample 2 & 0.09 & 0.01 & 99.90 \\
\hline sample 3 & 0.00 & 0.03 & 99.97 \\
\hline Mean & 0.06 & 0.03 & 99.92 \\
\hline Std. deviation & 0.06 & 0.01 & 0.05 \\
\hline
\end{tabular}

Table 9. Chemical composition of raw and treated sands from Assinie.

\begin{tabular}{|c|c|c|c|}
\hline \multicolumn{4}{|c|}{$(\mathrm{S} . \mathrm{S})_{\mathrm{ASS}, 0}$} \\
\hline \multirow{2}{*}{ Parameters } & \multicolumn{3}{|c|}{ Chemical compound } \\
\hline & $\mathrm{Al}_{2} \mathrm{O}_{3}(\%)$ & $\mathrm{FeO} / \mathrm{Fe}_{2} \mathrm{O}_{3}(\%)$ & $\mathrm{SiO}_{2}(\%)$ \\
\hline sample 1 & 1.40 & 0.19 & 98.41 \\
\hline sample 2 & 0.17 & 0.24 & 99.59 \\
\hline sample 3 & 1.28 & 0.26 & 98.46 \\
\hline Mean & 0.95 & 0.23 & 98.82 \\
\hline Std. deviation & 0.68 & 0.04 & 0.67 \\
\hline \multicolumn{4}{|c|}{$(\mathrm{S} . \mathrm{S})_{\mathrm{ASS}, 1}$} \\
\hline & $\mathrm{Al}_{2} \mathrm{O}_{3}(\%)$ & $\mathrm{FeO} / \mathrm{Fe}_{2} \mathrm{O}_{3}(\%)$ & $\mathrm{SiO}_{2}(\%)$ \\
\hline Sample 1 & 0.87 & 0.00 & 98.94 \\
\hline sample 2 & 0.22 & 0.12 & 99.53 \\
\hline sample 3 & 0.22 & 0.26 & 99.61 \\
\hline Mean & 0.44 & 0.13 & 99.44 \\
\hline Std. deviation & 0.37 & 0.13 & 0.27 \\
\hline
\end{tabular}


Energy dispersive spectrometry revealed that the raw sand from Maféré contains $98.73 \% \pm 0.15 \%$ silica. This sand also contains $0.94 \% \pm 0.07 \%$ iron oxide and $0.33 \% \pm 0.22 \%$ alumina. After treatment, the chemical composition of this sand changes. The proportion of mineral silica increases to $99.92 \% \pm 0.05 \%$. The content of other oxides is reduced. The iron oxide remains at $0.03 \% \pm 0.01 \%$ in this sand. And there remains $0.06 \% \pm 0.06 \%$ of alumina (see Table 8 ).

Moreover, the raw sand of Assinie contains $98.82 \% \pm 0.67 \%$ silica. This sand also contains $0.23 \% \pm 0.04 \%$ iron oxide and $0.95 \% \pm 0.68 \%$ alumina. After processing, the chemical composition of this sand also changes. The proportion of mineral silica increases to $99.44 \% \pm 0.27 \%$. The content of other oxides was reduced while the iron oxide remains at $0.13 \% \pm 0.13 \%$ and alumina at $0.44 \% \pm$ $0.37 \%$ (see Table 9).

The chemical compositions revealed by energy dispersive spectrometry are illustrated by the spectra in Figure 8 and Figure 9. These Figures showed the energy spectra of the six EDS analyses carried out on the sand of Maféré and Assinie respectively.
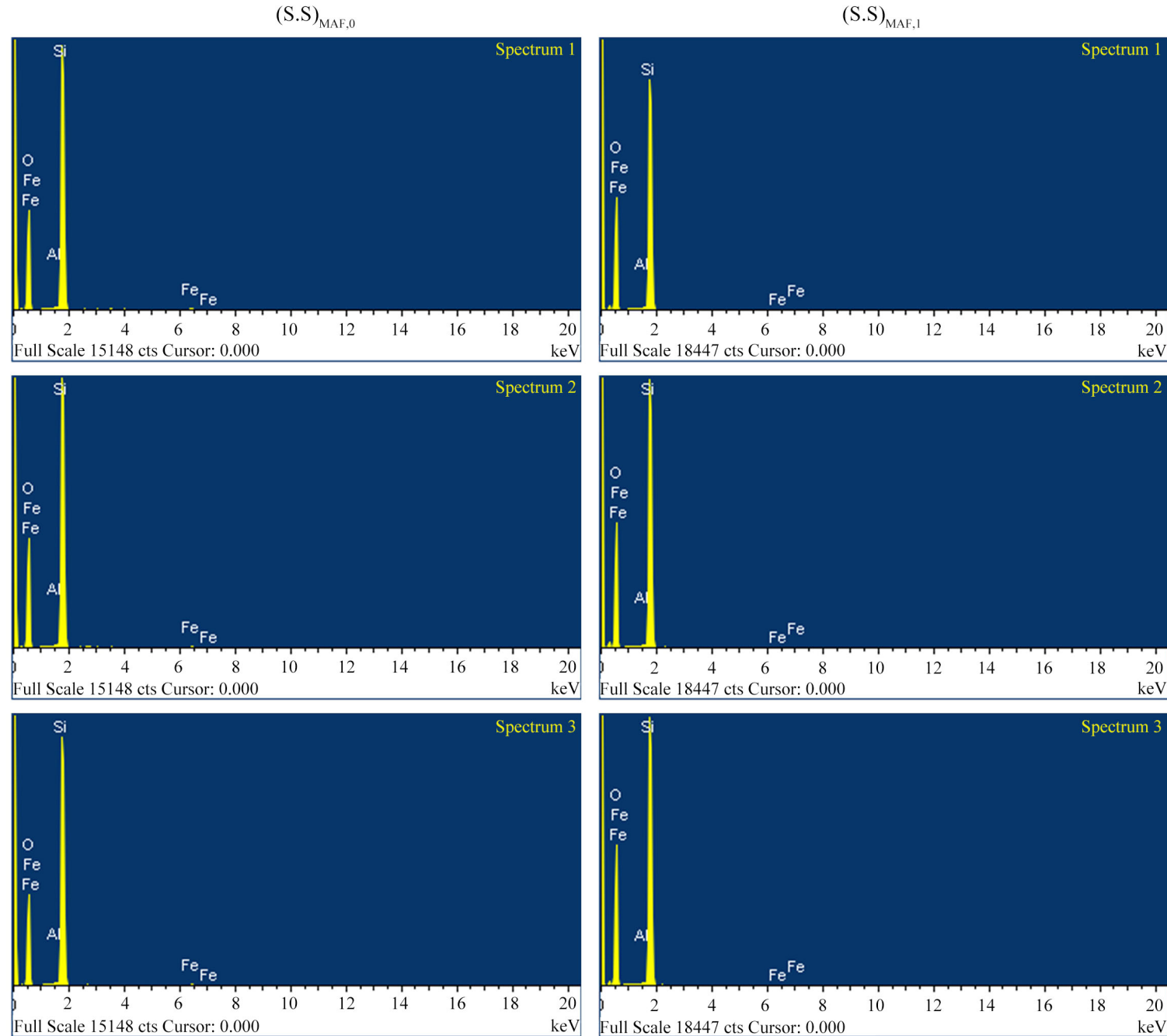

Figure 8. Energy dispersive spectra (EDS) of Maféré sand samples. 
(S.S) $)_{\mathrm{ASS}, 0}$
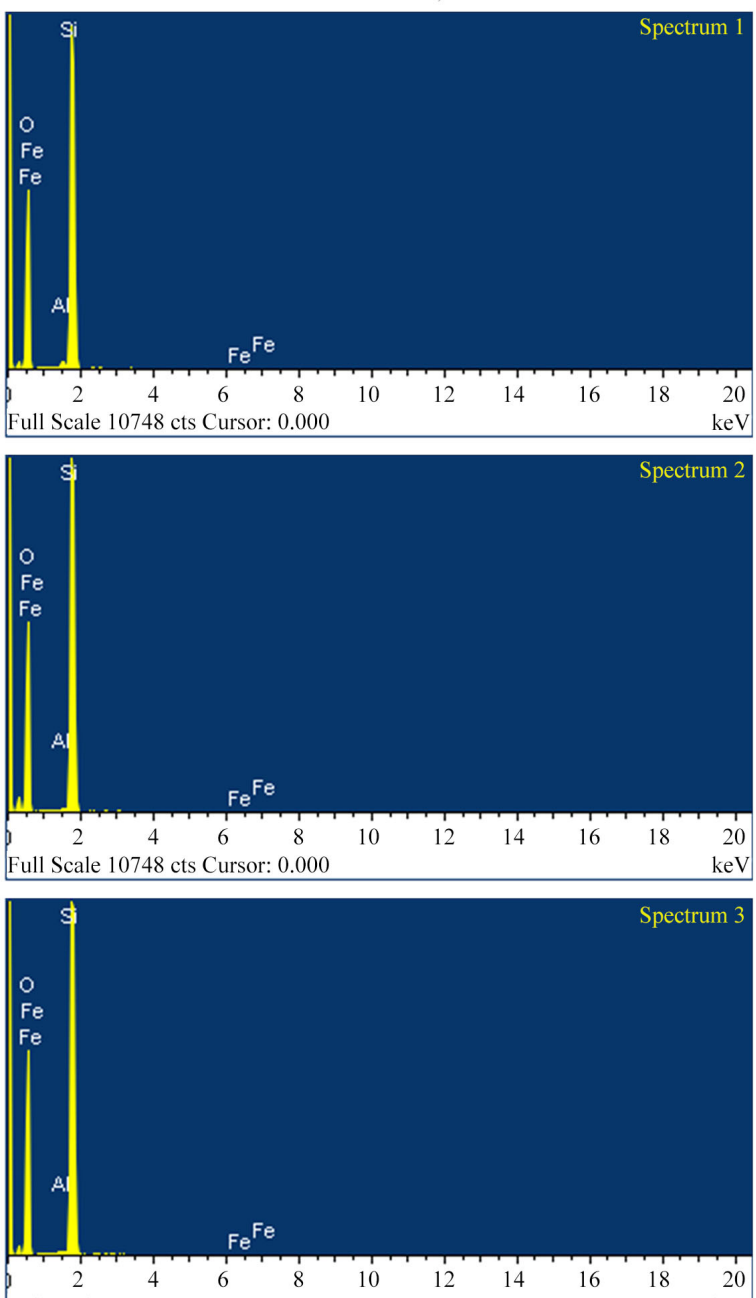

Full Scale 10748 cts Cursor: 0.000
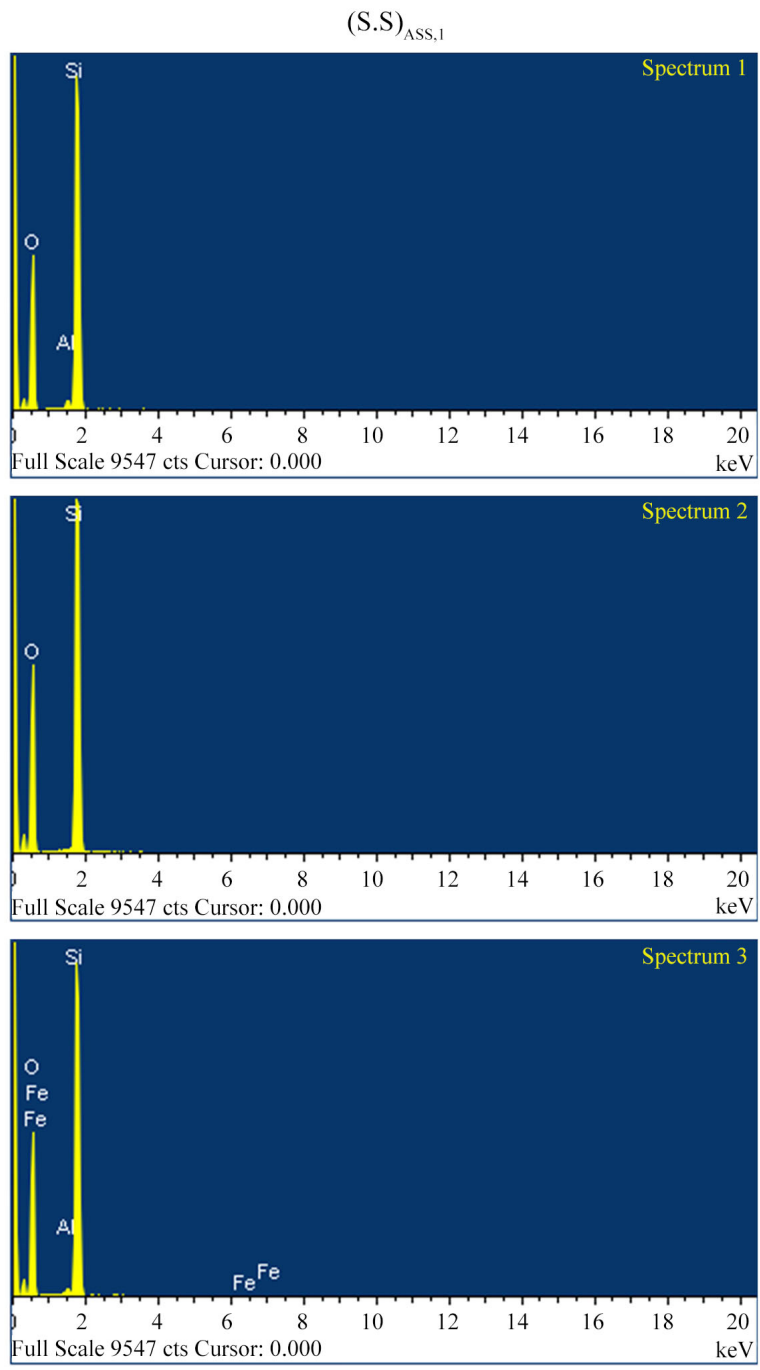

Figure 9. Energy dispersive spectra (EDS) of sand samples from Assinie.

The energy bands (in yellow) are characteristic of the chemical compounds present in the samples. Iron $(\mathrm{Fe})$ appears at several locations in these spectra. The multiple appearance of iron is explained by the fact that its detection depends on its degree of oxidation. Thus, it can be $\mathrm{FeO}, \mathrm{Fe}_{2} \mathrm{O}_{3}$ and $\mathrm{Fe}_{3} \mathrm{O}_{4}$. However, the proportion of iron in the samples is the accumulation of the rates of these different forms of oxidation detected.

\section{Processing weight efficiency}

The results of the performance evaluation of the treatment method employed using the formulas in Table 3 and Table 4 are in Table 10.

Wet sieving with attrition increased the silica content from $98.73 \%$ to $99.92 \%$, a yield of $93.7 \%$ for the Maféré sand, while for the sand of Assinie, the proportion of silica increases from $98.82 \%$ to $99.44 \%$, a yield of $52.53 \%$ (see Table 8 ). The rate of impurities in the sand of Maféré is reduced from $0.94 \%$ to $0.03 \%$, a yield of $96.81 \%$ for iron oxide, and a reduction from $0.33 \%$ to $0.06 \%$, a yield of $81.82 \%$ for alumina. 
Table 10. Performance of the treatment method used.

\begin{tabular}{ccc}
\hline \multirow{2}{*}{ Compound } & \multicolumn{2}{c}{ Processing weight efficiency } \\
\cline { 2 - 3 } & (MAF): Maféré Sample & (ASS): Assinie Sample \\
\hline Silica & $93.70 \%$ & $52.53 \%$ \\
Iron oxide & $96.81 \%$ & $76.92 \%$ \\
Alumina & $81.82 \%$ & $53.68 \%$ \\
\hline
\end{tabular}

In the sand of Assinie, the rate of impurities is also reduced after treatment. The content of iron oxide is reduced from $0.23 \%$ to $0.13 \%$, a yield of $76.92 \%$. A reduction from $0.95 \%$ to $0.44 \%$ is noted for alumina, a yield of $53.68 \%$.

Considering these results, we note that the treatment technique used allows the increase in the content of silica while reducing that of the other oxides. Better results were obtained in this study with the sand of Maféré compared to the result obtained by Marouan Khalifa et al. (2019) in their process to produce high purity silica sand by heat treatment and acid leaching process [21]. In addition, all our treated samples have a higher silica content (at least 99\%) than that of the samples obtained (98.1\%) in the work of Sundararajan et al. (2009) [13].

In the following, we present images of the samples. Also, the grain morphology of the sands was evaluated using scanning electron microscope (SEM).

\section{Micrography and Exoscopy of quartz grains}

Figure 10 and Figure 11 are images of the raw and processed samples from Assinie and Maféré. These images are visual indicators of the purification of these sands.

It was observed that the treated samples reflect more brightness (matte, vitreous) and color (white) of quartz (the natural silica). In the raw sand of Assinie, the treatment allows a notable reduction (as seen in Figure 10) of the organic matter (dark fraction)

The raw sand from Maféré has less organic matter than the sand from Assinie (Figure 11). However, there is more clay (very fine phase) in the sand of Maféré. The treatment reduces the proportion of clay and provides a sand containing clean quartz grains.

In addition, the SEM images below indicates the presence of different shapes of sand with irregular morphologies, for instance Figure 12 and Figure 13 show some rounded grains, whereas others are sub-rounded or elongated and sub-angular.

Generally, this indicates that the grains of these sands have undergone long transport, thereby, falls into the category of sands with blunt grains. Thus, these detritus have an origin further upstream in the crystalline basement of the Côte d'Ivoire.

Furthermore, the surface of the quartz grains observed at X500 magnification (see Figure 12(b); Figure 13(b)) is marked by numerous traces. The existence of these traces suggests a displacement of these grains in a turbulent environment. The primary deposits of these quartz grains are found in the basement rocks further upstream from the sampling sites. 


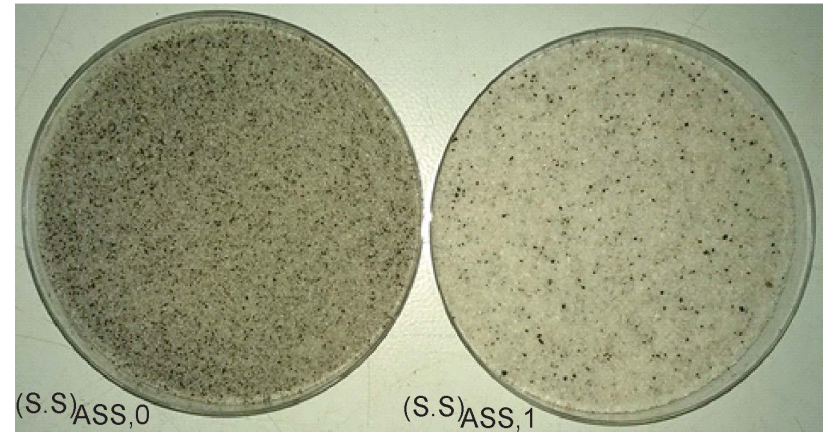

(a)

(b)

Figure 10. Photograph of raw (a) and processed (b) sample from Assinie.

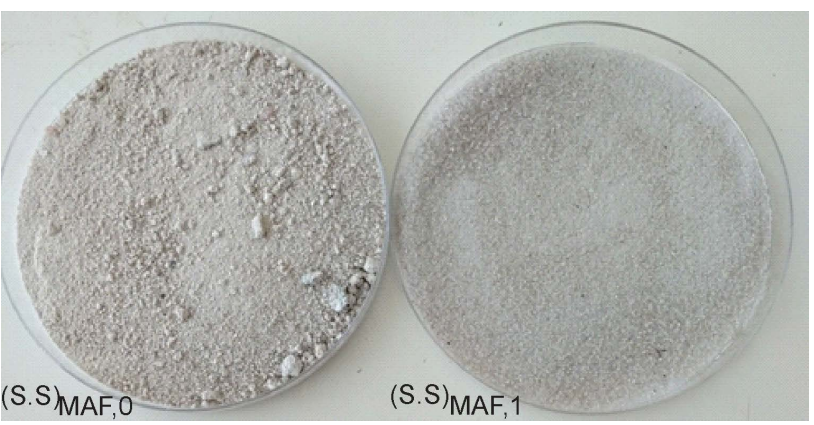

(a) (b)

Figure 11. Photograph of raw (a) and processed (b) sample from Maféré.

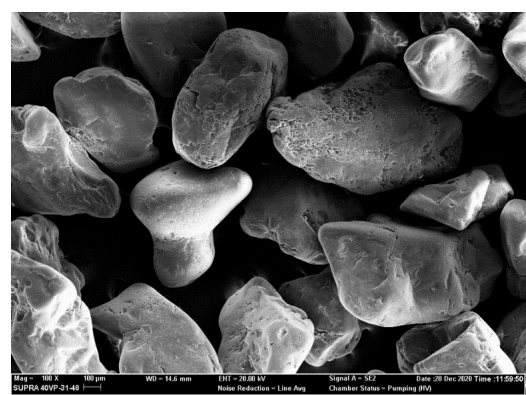

(a)

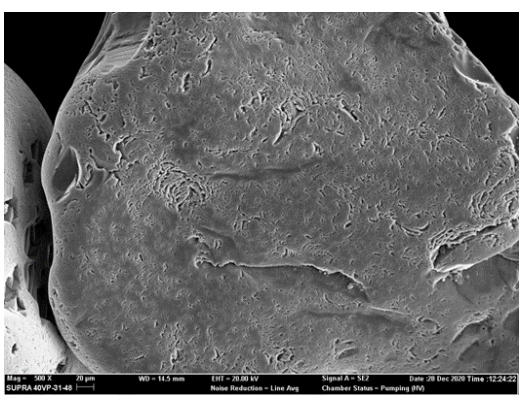

(b)

Figure 12. Exoscopy of quartz grains from the Assinie sand. (a) 100X magnification; (b) 500X magnification

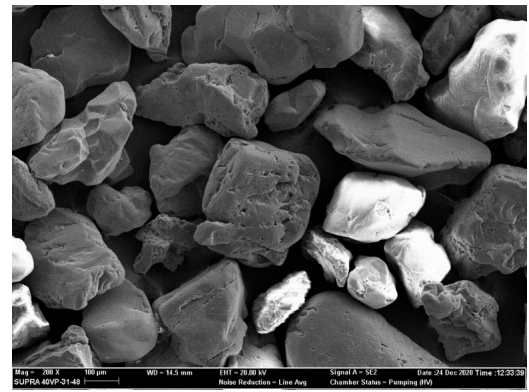

(a)

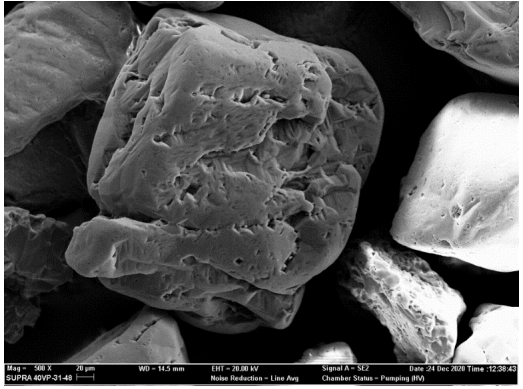

(b)

Figure 13. Exoscopy of quartz grains from the Maféré sand. (a) 100X magnification; (b) 500X magnification. 


\section{Conclusions}

We have carried out a purification treatment of sand samples taken from the sedimentary basin of Ivory Coast in West Africa. The objective of this study was to obtain silica sand ideal to produce glazing glass. Wet sieving and attrition technique were implemented in this purification process. The results from the analysis of the chemical composition of the raw and treated samples show a significant increase in the silica content and a significant reduction of impurities. The silica content $\left(\mathrm{SiO}_{2}\right)$ of the Maféré sand increased from $98.73 \% \pm 0.15 \%$ to $99.92 \% \pm 0.05 \%$, i.e., a yield of $93.70 \%$, while of Assinie increased from $98.82 \% \pm$ $0.67 \%$ in the raw samples to $99.44 \% \pm 0.27 \%$ after treatment, a yield of $52.53 \%$. The rate of iron oxide is reduced from $96.81 \%$ for the sand of Maféré against $76.92 \%$ for that of Assinie. Also, the proportion of alumina is reduced by $81.82 \%$ against $53.68 \%$ for the sand of Maféré and Assinie respectively. The sand of Maféré contains $53.2 \%$ of grains smaller than 500 microns and that of Assinie contains $29.30 \%$. The technique of treatment used is more effective for the sand of Maféré containing more clay. Regarding the chemical composition of the said purified sands, they comply with the standard BS2975s of the American Ceramic Society and the National Bureau of Standards for the manufacture of window glass.

These results pave the way for feasibility studies for the opening of a sand quarry on these sites.

\section{Conflicts of Interest}

The authors declare no conflicts of interest regarding the publication of this paper.

\section{References}

[1] Marteau, H.L., P.avec la collaboration, de Chassagnac, D., Jallon, S. and Lefebvre, G. (2016) Mémento Silice industrielle. Rapport BRGM/RP-66167-FR, Bureau de Recherches Géologiques et Minières, Orléans, $66 \mathrm{p}$.

[2] Anas Boussaa, S., Kheloufi, A., Zaourar, N.B. and Kerkar, F. (2016) Valorization of Algerian Sand for Photovoltaic Application. Acta Physica Polonica A, 130, 133-137. https://doi.org/10.12693/APhysPolA.130.133

[3] Anas Boussaa, S., Kheloufi, A. and Boutarek, N.Z. (2018) Caractérisation et valorisation du Quartz d'Edough pour application photovoltaïque. Revue des Energies Renouvelables, 21, 391-396.

[4] Anas Boussaa, S., Kheloufi, A. and Zaourar, N.B. (2018) Sand Dune Characterization for Preparing Metallurgical Grade Silicon. Open Chemistry, 16, 1227-1232. https://doi.org/10.1515/chem-2018-0128

[5] Anas Boussaa, S., Kheloufi, A., Zaourar, N.B., Kefaifi, A. and Kerkar, F. (2016) Characterization of Silica Quartz as Raw Material in Photovoltaic Applications. AIP Conference Proceedings, 1758, Article ID: 030043.

https://doi.org/10.1063/1.4959439

[6] Anas Boussaa, S., Kheloufi, A., Zaourar, N.B., Kerkar, F. and Kefaifi, A. (2016) Physico-Chemical Characterization of Bechar Sand-Valorization for Silicon Production. 
Revue des Energies Renouvelables, 19, 481-486.

[7] Bonnet, C. (2010) La silice industrielle.

[8] Odewale, I.O., Ajala, L.O. and Tse, D.T. (2013) Characterizaton of Unwana Beach Silica Sand and Its Industrial Applications. International Journal of Science Innovations and Discoveries, 3, 93-103.

[9] British Standards Institution (2008) BS: 2975-2. British Standard Methods for Sampling and Analysis of Glass-Making Sands-Part 2: Methods for Chemical Analysis. British Standards Institution, London, 30.

[10] Thio, R.P., Konan, D.K., Koffi, B.K. and Yao, A.K. (2020) Characterization of Raw Silica Sand from the Ivorian Sedimentary Basin for Silica Glass Making. Journal of Materials and Environmental Science, 11, 2016-2024. (In English)

[11] Fournier, J., Bonnot-Courtois, C., Paris, R., Voldoire, O. and Vot, M.L. (2012) Analyses granulométriques, principes et méthodes. Centre national de la recherche scientifique, Dinard, 99 p.

[12] Roose, E. and Cheroux, M. (1996) Les sols du basin sédimentaire de Côte d'Ivoire. O.R.S.T.O.M. Adiopodoumé, Côte d'Ivoire.

[13] Sundararajan, M., Ramaswamy, S. and Raghavan, P. (2009) Evaluation for the Beneficiability of White Silica Sands from the Overburden of Lignite Mine situated in Rajpardi District of Gujarat, India. Journal of Minerals \& Materials Characterization \& Engineering, 8, 701-713. https://doi.org/10.4236/jmmce.2009.89061

[14] Bouabdallah, S. (2016) Caractérisation-enrichissement des grès pauvres d'el-aouana: Cas de l'usine de verre (africaver) / jijel. Thèse de doctorat en Valorisation et Gestion des Ressources Minérales. Badji Mokhtar Annaba University, Annaba.

[15] EL-Wekeil, S.S. and Gaafar, F.Sh. (2014) Characterization and Economic Potential of the White Sandstones of the Naqus Formation in Wadi Qena, Northern Eastern Desert, Egypt. Middle East Journal of Applied Sciences, 4, 392-408.

[16] Salopek, B., Sobota, I., Halle, R. and Bedeković, G. (2004) Improvement of Quartz Sand Quality Using Attrition Cleaning. Proceedings of the 13 th International Symposium on Mine Planning and Equipment Selection, Wroclaw, 1-3 September 2004, 303-308.

[17] Ibrahim, S.S., Selim, A.Q. and Hagrass, A.A. (2013) Gravity Separation of Silica Sands for Value Addition. Particulate Science and Technology, 31, 590-595. https://doi.org/10.1080/02726351.2013.800930

[18] Thirion-Merle, V. (2014) Spectrométrie de fluorescence X. In: Philippe, D. and Ludovic, B.-G., Eds., Circulation et provenance des matériaux dans les sociétés anciennes, Editions des archives contemporaines, Collection Sciences Archéologiques, France, 291-298. https://doi.org/10.17184/eac.4103

[19] Wang, R. (2016) Dopage de nanostructure de carbone pour l'émission de champ. Thèse de doctorat en Science et génie des matériaux, Université de Toulouse, Toulouse.

[20] Blott, S.J. and Pye, K. (2001) Gradistat: A Grain Size Distribution and Statistics Package for the Analysis of Unconsolidated Sediments. Earth Surface Processes and Landforms, 26, 1237-1248. https://doi.org/10.1002/esp.261

[21] Khalifa, M., Ouertani, R., Hajjia, M. and Ezzaouia, H. (2019) Innovative Technology for the Production of High-Purity Sand Silica by Thermal Treatment and Acid Leaching Process. Hydrometallurgy, 185, 204-209. https://doi.org/10.1016/j.hydromet.2019.02.010

[22] Krinsley, D.H. and Doornkamp, J.C. (1973) Atlas of Quartz Sand Surface Textures. 
Cambridge University Press, London, 102 p.

[23] Mahaney, W.C. (2002) Atlas of Sand Grain Surface Textures and Applications. Oxford University Press, Oxford. 